\title{
Plasma Warfarin Level and International Normalized Ratio do not Correlate with Bleeding Events in Indonesian Patients of Minangkabau Ethnicity with Atrial Fibrillation
}

\author{
Rahmatini Rahmatini ${ }^{1}$, Gestina Aliska ${ }^{1}$, Elly Usman ${ }^{1}$, Mefri Yanni ${ }^{2}$, Cimi Ilmiawati ${ }^{1 *}$ \\ ${ }^{1}$ Department of Pharmacology and Therapeutics, Faculty of Medicine, Andalas University, Padang, West Sumatera, Indonesia; \\ ${ }^{2}$ Department of Cardiology and Vascular Medicine, Faculty of Medicine, Andalas University, Padang, West Sumatera, \\ Indonesia
}

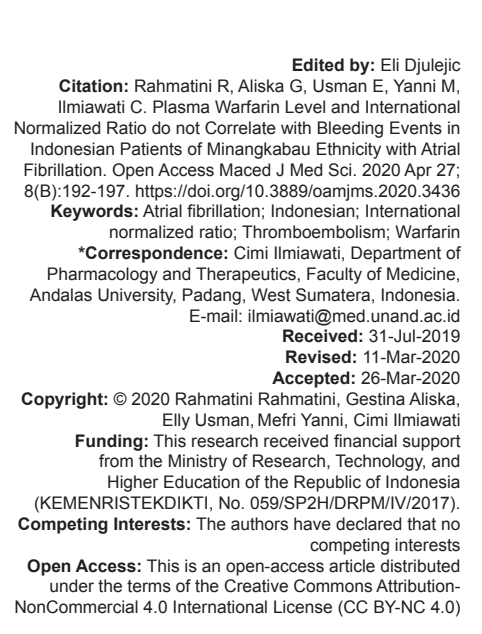

\section{Introduction}

Atrial fibrillation (AF) is the most common type of arrhythmias and the global burden of AF is increasing progressively [1]. The prevalence of AF in some countries in Europe ranges from $1.9 \%$ to $2.9 \%$ [2]. The incidence rates in developed regions were significantly higher compared with developing countries [1]. However, AF prevalence in Indonesian National Heart Center in 2013 was $9.8 \%$ [3]. The high prevalence of AF makes the treatment of AF and factors contributing to treatment efficacy a critical field to study in Indonesia.

Arrhythmic, particularly AF, patients were commonly treated with the oral anticoagulant warfarin. Warfarin has a narrow therapeutic index. Furthermore, warfarin binds strongly to albumin; therefore, it may shift the bond of other drugs to albumin when given simultaneously, thus reducing the effectiveness of other medications [4]. The amount of administered dose must be individualized by considering each patient's clinical features, by measuring prothrombin time periodically, and by noting the tendency for the occurrence of bleeding [5]. The therapeutic range of oral anticoagulants is expressed by the International Normalized Ratio (INR) calculated based on prothrombin time. In general, the INR value of 2.0-3.0 is considered within the therapeutic range. INR value is used as a guide for dose adjustment in patients receiving warfarin [6]. Patients with periodical INR value within the therapeutic range $70 \%$ of the time or more had a significantly reduced risk of stroke [7]. Determination of warfarin plasma concentration is an objective procedure to ascertain drug concentration in the blood. Some patients may show resistance to warfarin and, thus, may require an increased dose. Warfarin resistance is shown to be associated with genetic abnormalities or the presence of genetic polymorphisms, particularly on CYP2C9 and VKORC1 [8], [9]. Asians, AfricanAmericans, and Native Americans combined had lower mean time in therapeutic range compared with European patients receiving warfarin [10]. Ethnicspecific dosing algorithms are thought to be crucial in pharmacogenetics-guided warfarin therapy [11]. 
However, first, we need to ascertain warfarin plasma level in the ethnic group of interest.

Up until now, there is no data on warfarin plasma concentration in the Indonesian population of Minangkabau ethnic origin suffering from AF. As Indonesia is a multi-ethnic country, ethnic-specific information is valuable in identifying pharmacokinetics variation among patients. The setting of the current study was a general referral hospital in the capital of West Sumatera Province, where Minangkabau ethnic resides. Most patients' medication was covered by a national health insurance system. Patients were referred by primary care physicians to the cardiology department of the hospital to receive specialized care for their AF. In this study, we investigated warfarin plasma concentration to identify pharmacokinetics variation that might impact warfarin efficacy in our patients.

\section{Materials and Methods}

\section{Study subjects}

This study was a cross-sectional study conducted from January to November 2017 in Indonesian patients of Minangkabau ethnicity with AF receiving warfarin therapy at a tertiary hospital in West Sumatra, Indonesia. The study was performed according to the Declaration of Helsinki and approved by the Ethical Committee (Institutional Review Board) of the Faculty of Medicine, Andalas University (Ref No. 177/KEP/FK/2017). Blood samples used in the study were collected at a single time point from patients attending outpatient clinic at the Department of Cardiology and Vascular Medicine, M. Djamil General Hospital, Padang, West Sumatra, who had received oral anticoagulant warfarin for at least 5 weeks. Patients were male or female above 18 years old diagnosed with AF based on standard diagnostic criteria [12]. Those with impaired liver and kidney function and pregnancy were excluded from the study.

Bleeding event as the side effect of oral anticoagulant therapy was defined according to the Bleeding Academic Research Consortium definition [13] and it was assessed by history taking at the time of sample collection. The bleeding event in this study was either Type 0 (no evidence of bleeding) or Type 1 (bleeding that is not actionable and does not cause the patient to seek treatment by a health-care professional) during the past 5 weeks. Patients' 1-year risk of major bleeding was assessed by calculating their hypertension, abnormal liver/renal function, stroke, bleeding history or predisposition, and labile INRs (HAS-BLED) score [14]. All patients were taking medications other than warfarin, and these drugs were listed and checked for their interaction with warfarin.

\section{Plasma warfarin analysis}

Plasma warfarin analysis was performed by Pharmametric Laboratory, Jakarta. The method was as followed. Three milliliters of blood was drawn from the vein by using Vacutainer ${ }^{\circledR}$, inverted and centrifuged at $3,000 \mathrm{rpm}$ for $10 \mathrm{~min}$. Plasma was immediately separated, aliquoted, and stored at $-20^{\circ} \mathrm{C}$ for $<1$ month before analysis. High-performance liquid chromatography was used to measure plasma warfarin concentration using a $\mathrm{C} 18$ column with mobile phase acetonitrile and $0.5 \%$ triethylamine at a ratio of 28:72; $\mathrm{pH} \mathrm{6.5;} \mathrm{and} \mathrm{flow} \mathrm{velocity} 1.0 \mathrm{ml} / \mathrm{min}$ at $386 \mathrm{~nm}$ [15], [16], [17].

\section{Statistical analysis}

Categorical data were presented in a frequency distribution, and continuous data were presented in mean, median, and range. The correlation of administered warfarin dose with plasma warfarin level and INR value was analyzed by Spearman's rank correlation due to the non-normal distribution of the data. The difference in INR and plasma warfarin levels in subjects with and without bleeding events was analyzed by the Mann-Whitney $U$ test. Statistical significance was set at $p<0.05$. All statistical analyses were performed using IBM $^{\circledR}$ SPSS $^{\circledR}$ Statistics ver.19 (IBM, US).

\section{Results}

There were 45 subjects with AF who met inclusion criteria and agreed to participate in the study with characteristics, as shown in Table 1. The median warfarin plasma concentration was $0.94 \mu \mathrm{g} / \mathrm{ml}$ with a median maintenance dose of $2.5 \mathrm{mg} /$ day. More than half $(55.6 \%)$ of patients had INR value $<2.0$ and only $28.9 \%$ of patients reached the desirable INR value of 2.0-3.0, while the rest (15.6\%) showed value $>3.0$ [7].

Warfarin dose was found to be statistically significantly correlated with plasma warfarin level, albeit with moderate positive correlation $(r=0.459$, $p=0.002$; Figure 1a). However, warfarin dose and plasma warfarin levels were not significantly correlated with INR $(r=-0.032, p=0.83$; Figure $1 b$ and $r=0.273$, $\mathrm{p}=0.07$; Figure 1c, respectively).

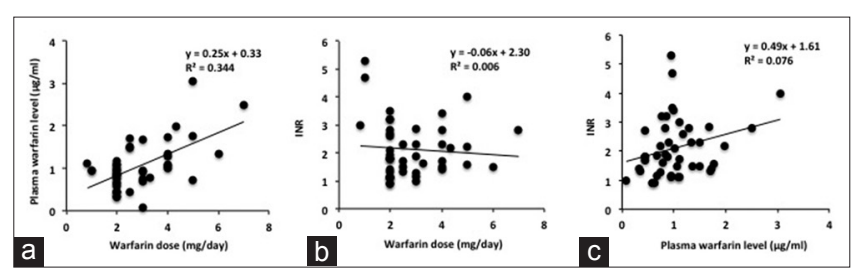

Figure 1: Correlations of warfarin dose with plasma warfarin level (a) and international normalized ratio (INR) (b), and correlation of plasma warfarin level with INR (c) in 45 patients with atrial fibrillation 
Table 1: Characteristics of subjects

\begin{tabular}{|c|c|c|c|c|c|c|c|}
\hline Characteristics & $\mathrm{n}$ & (\%) & $\mathrm{AM}^{\mathrm{a}}$ & $\mathrm{GM}^{\mathrm{b}}$ & Median & Min & $\operatorname{Max}$ \\
\hline Age (year) & 45 & (100) & 54.6 & & & 25 & 80 \\
\hline \multicolumn{8}{|l|}{ Sex } \\
\hline Male & 25 & $(55.6)$ & & & & & \\
\hline Female & 20 & $(44.4)$ & & & & & \\
\hline Body mass index $\left(\mathrm{kg} / \mathrm{m}^{2}\right)$ & 45 & (100) & 22.9 & & & 17.6 & 29.3 \\
\hline \multicolumn{8}{|l|}{ Level of education } \\
\hline Primary & 14 & (31.1) & & & & & \\
\hline Secondary & 28 & $(62.2)$ & & & & & \\
\hline Graduate/postgraduate & 3 & $(6.7)$ & & & & & \\
\hline \multicolumn{8}{|l|}{ Occupation } \\
\hline Civil servant & 5 & (11.1) & & & & & \\
\hline Self-employed & 13 & $(28.9)$ & & & & & \\
\hline Housewife & 18 & $(40.0)$ & & & & & \\
\hline Retiree & 9 & $(20.0)$ & & & & & \\
\hline Warfarin dose (mg/day) & 45 & (100) & 2.9 & 2.6 & 2.5 & 0.8 & 7.0 \\
\hline INR & 45 & (100) & 2.1 & 1.9 & 1.8 & 0.9 & 5.3 \\
\hline$<2.0$ & 25 & (55.6) & & & & & \\
\hline $2.0-3.0$ & 13 & (28.9) & & & & & \\
\hline$>3.0$ & 7 & (15.6) & & & & & \\
\hline Plasma warfarin $(\mu \mathrm{g} / \mathrm{ml})$ & 45 & (100) & 1.1 & 0.90 & 0.94 & 0.1 & 3.1 \\
\hline$<1.0$ & 23 & (51.1) & & & & & \\
\hline $1.0-2.0$ & 20 & (44.4) & & & & & \\
\hline$>2.0$ & 2 & $(4.4)$ & & & & & \\
\hline Side effect occurrence & 38 & (100) & & & & & \\
\hline None & 24 & (63.2) & & & & & \\
\hline Bleeding & 14 & $(36.8)$ & & & & & \\
\hline \multicolumn{8}{|l|}{${ }^{\text {aArithmetic mean }}$} \\
\hline${ }^{\mathrm{b}}$ Geometric mean & & & & & & & \\
\hline
\end{tabular}

To explore the relationship between bleeding event occurrence with plasma warfarin level and INR in our subjects, we compared plasma warfarin level and INR in those without $(n=24)$ and with $(n=14)$ bleeding events. Patients whose information on bleeding events unavailable $(n=7)$ were not included in the analysis. Those with bleeding events had lower plasma warfarin levels $(p=0.05)$ and higher INR $(p=0.12)$, albeit statistically non-significant, compared to those without bleeding events (Figure 2).
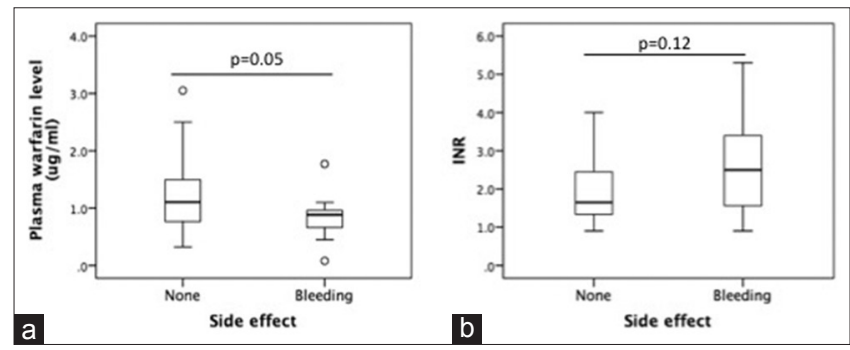

Figure 2: Association of plasma warfarin level (a) and international normalized ratio (b) with occurrence of bleeding event in 45 patients with atrial fibrillation

To predict major bleeding risk in anticoagulated AS patients, we calculated the HAS-BLED score [14] and presented the result in Table 2. More than half $(57.8 \%)$ of the patients were categorized to moderate risk (HAS-BLED score $1-2)$ and the rest $(42.2 \%)$ were categorized to a high risk of major bleeding (HAS-BLED score $\geq 3$ ).

Table 2: Bleeding risk in AF patients based on HAS-BLED* score

\begin{tabular}{llll}
\hline HAS-BLED score & Frequency & Percent & Risk category \\
\hline 1 & 9 & 20 & Moderate \\
2 & 17 & 37.8 & High \\
3 & 16 & 35.6 & \\
4 & 1 & 2.2 & \\
5 & 1 & 2.2 & \\
6 & 1 & 2.2 & \\
Total & 45 & 100 & \\
\hline${ }^{*}$ HAS-BLED: Hypertension, abnormal liver/renal function, stroke, bleeding history or predisposition, labile
\end{tabular}

INRs, elderly (age>65), drugs or alcohol. INR: International normalized ratio, AF: Atrial fibrillation.
To consider the possible pharmacokinetic interaction between warfarin and other drugs affecting warfarin plasma levels, we have compiled all the drugs administered to the patients in Table 3. There were four drugs that might have a major and a moderate interaction with warfarin, and there were six drugs that might have minor interaction with warfarin, taken by the patients.

Table 3: List of drugs administered to the warfarin-taking patients

\begin{tabular}{|c|c|c|c|}
\hline Drug class & Drug name & $\begin{array}{l}\text { Known } \\
\text { interaction } \\
\text { with warfarin }\end{array}$ & $\begin{array}{l}\text { Number of } \\
\text { patients taking } \\
\text { the drug }\end{array}$ \\
\hline \multirow[t]{3}{*}{ Antiplatelet } & Acetosal & Major & 5 \\
\hline & Cilostazol & Major & 1 \\
\hline & Clopidogrel & Major & 1 \\
\hline \multirow[t]{3}{*}{ Beta-blocker } & Bisoprolol & No & 40 \\
\hline & Carvedilol & No & 4 \\
\hline & Propranolol & Minor & 1 \\
\hline Loop-diuretic & Furosemide & Minor & 29 \\
\hline Potassium-sparing diuretic & Spironolactone & Minor & 21 \\
\hline \multirow[t]{3}{*}{ Angiotensin receptor blocker } & Candesartan & No & 8 \\
\hline & Telmisartan & Minor & 3 \\
\hline & Valsartan & No & 1 \\
\hline \multirow[t]{2}{*}{ ACE-inhibitor } & Ramipril & No & 12 \\
\hline & Lisinopril & No & 1 \\
\hline \multirow[t]{2}{*}{ Calcium-channel blocker } & Amlodipine & No & 4 \\
\hline & Nifedipine & No & 1 \\
\hline Cardiac glycoside & Digoxin & No & 5 \\
\hline \multirow[t]{2}{*}{ Statin } & Atorvastatin & Minor & 11 \\
\hline & Simvastatin & Minor & 1 \\
\hline Nitrate & Isosorbide dinitrate & No & 2 \\
\hline \multirow[t]{2}{*}{ Uric acid medication } & Allopurinol & Moderate & 3 \\
\hline & Colchicine & No & 1 \\
\hline \multirow[t]{2}{*}{ Proton-pump inhibitor } & Lansoprazole & Moderate & 12 \\
\hline & Omeprazole & Moderate & 1 \\
\hline Mucosal protector & Sucralfate & Moderate & 2 \\
\hline \multirow[t]{2}{*}{ Laxative } & Psyllium & No & 1 \\
\hline & Laxadine $^{\mathrm{TM}}$ & No & 1 \\
\hline Antibiotics & Ciprofloxacin & Major & 1 \\
\hline Benzodiazepine & Clobazam & No & 1 \\
\hline \multirow[t]{3}{*}{ Others } & Vitamin B & No & 5 \\
\hline & Folic acid & No & 1 \\
\hline & Acetyl cysteine & No & 1 \\
\hline
\end{tabular}

\section{Discussion}

The mean warfarin plasma concentration of patients with AF in this study was $1.1 \pm 0.6$ (range, 
0.1-3.1) $\mu \mathrm{g} / \mathrm{ml}$. It was achieved with a maintenance dose of $2.9 \pm 1.3$ (range, $0.8-7.0$ ) $\mathrm{mg} /$ day. This result is higher than that of a study in Chinese patients with heart valve replacement within 1 month of post-operation, where the mean of warfarin plasma concentration was $0.6 \pm 0.12 \mu \mathrm{g} / \mathrm{ml}$ [18]. However, our finding is similar to a study in Korean patients $(1.3 \pm 0.5 \mu \mathrm{g} / \mathrm{ml})$ administered a higher maintenance dose of $4.1 \pm 1.3 \mathrm{mg} /$ day (range, 1.7-8.0 mg/day) than our patients [19]. Polymorphisms in a gene such as VKORC1, CYP2C9 [8], [9], [10], [11], and CYP4F2 [20] may contribute to the differences in plasma warfarin levels.

Warfarin is a Vitamin $\mathrm{K}$ antagonist with the anticoagulant effect mediated through the prevention of activation of Vitamin $\mathrm{K}$ dependent coagulation factors (factor II, VII, IX, and X) [21] age [22], fat-free mass [23], Vitamin K-rich foods, and coadministered drugs [24] are determinants of warfarin pharmacokinetics. It is estimated that pharmacokinetics factors determine up to $40 \%$ of warfarin maintenance dose variability [24], [25]. We have listed coadministered drugs in our patients and found that eight patients were taking drugs with significant interaction with warfarin. This possible interaction may influence the correlation between plasma warfarin levels and INR. Furthermore, genetic variations of VKORC1 and Vitamin $\mathrm{K}$ intake influence warfarin dose and anticoagulation response [26]. With a narrow therapeutic window and a high inter- and intra-individual variability, warfarin use needs careful laboratory monitoring and dose adjustment to gain antithrombotic protection while minimizing the bleeding risk.

Warfarin dose was found to be correlated with plasma warfarin levels. However, plasma warfarin level was not significantly correlated with INR, despite a trend of increasing INR with increasing plasma warfarin level. These results confirmed the finding of a previous study where the INR is poorly dependent on warfarin concentration [27]. Previous studies in Indonesians receiving low-dose warfarin therapy found that a high INR is associated with polymorphisms in VKORC1 and CYP2C9 [28], and both genes showed significant association with warfarin sensitivity [9]. Whether these major genetic factors played a role in the pharmacokinetics and/or pharmacodynamics in our subjects, remain to be elucidated.

This study finds that less than a third of patients who received doses of $0.8-7.0 \mathrm{mg} / \mathrm{day}$ of warfarin had INR value within the optimal warfarin therapy range (2.0-3.0). One study reported that stable anticoagulation was achieved in $80 \%$ of patients who received doses of 2-5 mg/day of warfarin [29]. Previous studies had demonstrated the importance of maintaining a stable INR value between 2.0 and 3.0 for reducing strokes and mortality in patients with AF [7]. When INR value remained within the therapeutic range of more than $70 \%$ of the time, there is a substantially lower risk of stroke [30]. A previous study showed that
INR value 2.0-3.0 was associated with a reduced risk of clinically significant bleeding [31]. In this study, the INR value was not correlated to the incidence of bleeding. Despite the HAS-BLED score showing our patients having moderate to high risk of major bleeding, the bleeding episodes in this study were minor, and HAS-BLED score was not correlated with plasma warfarin level (data not shown). Diets, age, drug interactions, and genetic polymorphisms are known to link with warfarin metabolism. In this study, age was not associated with INR or plasma warfarin (data not shown).

The limitation of this study was that data were obtained from a single center with a small number of patients. Nevertheless, this is the first plasma warfarin monitoring study in warfarin-treated AF patients from the Indonesian ethnic of Minangkabau. The current study did not encompass patients' clinical outcomes on follow-up, and therefore further studies are warranted.

\section{Conclusion}

Neither warfarin plasma concentration nor INR was correlated with bleeding events in Indonesian patients of Minangkabau ethnicity with AF. Future endeavor is recommended in a more extensive study to explore the genetic variants contributing to warfarin pharmacokinetics/pharmacodynamics in this population.

\section{Acknowledgments}

This study was funded by a grant from the Ministry of Research, Technology, and Higher Education (KEMENRISTEKDIKTI) of the Republic of Indonesia (059/SP2H/DRPM/IV/2017) to RR. The funding organization played no role in the study design; in the collection, analysis, and interpretation of data; in the writing of the report; or in the decision to submit the report for publication.

\section{References}

1. Chug SS, Havmoeller R, Narayanan K, Singh D, Rienstra M, Benjamin EJ, et al. Worldwide epidemiology of atrial fibrillation: A global burden of disease 2010 study. Circulation. 2014;129(8):837-47. https://doi.org/10.1161/ circulationaha.113.005119

PMid:24345399 
2. Zoni-Berisso M, Lercari, Carazza T, Domenicucci S Epidemiology of atrial fibrillation: European perspective. Clin Epidemiol. 2014;6:213-20. https://doi.org/10.2147/clep.s47385 PMid:24966695

3. PERKI. 2014. Pedoman tata Laksana Fibrilasi Atrium (Atrial Fibrillation Management Guideline). Perhimpunan Dokter Spesialis Kardiovaskular Indonesia (Indonesian Heart Association). Centra Communications. $1^{\text {st }}$ ed. Jakarta, Indonesia: Indonesian Heart Association. p. 11-35. Available from: http://www.inaheart.org/upload/file/FA_Final_Launch.pdf. [Last accessed on 2018 Mar 20].

4. Zehnder JL. Drugs used in disorders of coagulation. In: Katzung BG, SB Masters, Trevor AJ, editors. Basic and Clinical Pharmacology. $11^{\text {th }}$ ed. Singapore: McGraw-Hill; 2009. p. 598-99.

5. Boroumand M, Goodarzynejad H. Monitoring of anticoagulant therapy in heart disease: Considerations for the current assays. J Tehran Heart Center 2010;5(2):57-68. PMid:23074569

6. Setiabudi E, Alwi I, Setiati S. Oral anticoagulant treatment in management of elderly patients with atrial fibrillation: Is it beneficial or detrimental? Acta Med Indones. 2008;40(1):40-7. PMid:18326899

7. Morgan CL, McEwan P, Tukiendorf A, Robinson PA, Clemens A, Plumb JM. Warfarin treatment in patients with atrial fibrillation: Observing outcomes associated with varying concentrations of INR control. Thromb Res. 2009;124(1):37-41. https://doi. org/10.1016/j.thromres.2008.09.016

PMid:19062079

8. Sconce EA, Khan TI, Wynne HA, Avery P, Monkhouse L, King BP, et al. The impact of CYP2C9 and VKORC1 genetic polymorphism and patient characteristics upon warfarin dose requirements: Proposal for a new dosing regimen. Blood. 2005;106(7):232933. https://doi.org/10.1182/blood-2005-03-1108 PMid:15947090

9. Suriapranata IM, Tjong WY, Wang T, Utama A, Raharjo SB, Yuniadi $\mathrm{Y}$, et al. Genetic factors associated with patientspecific warfarin dose in ethnic Indonesians. BMC Med Genet. 2011;12:80. https://doi.org/10.1186/1471-2350-12-80 PMid:21639946

10. Yong C, Azarbal F, Abnousi F, Heidenreich P, Schmitt S, Fan J, et al. Racial differences in quality of anticoagulation therapy for atrial fibrillation (from the TREAT-AF study). Am J Cardiol. 2016;117:61-8. https://doi.org/10.1016/j.amjcard.2015.09.047 PMid:26552504

11. Fung E, Patsopoulos NA, Belknap SM, O'Rourke DJ, Robb JF, Anderson $\mathrm{JL}$, et al. Effect of genetic variants, especially CYP2C9 and VKORC1, on the pharmacology of warfarin. Semin Thromb Hemost. 2012;38:893-904. https://doi. org/10.1055/s-0032-1328891 PMid:23041981

12. January CT, Wann LS, Alpert JS, Calkins H, Cigarroa JE, Cleveland JC Jr., et al. AHA/ACC/HRS guideline for the management of patients with atrial fibrillation: Executive summary: A report of the American College of cardiology/ American heart association task force on practice guidelines and the heart rhythm society. Circulation. 2014;130:2071-104. https://doi.org/10.1161/cir.0000000000000040 PMid:24682348

13. Mehran R, Rao SV, Bhatt DL, Gibson M, Caixeta A, Eikelboom J. Standardized bleeding definitions for cardiovascular clinical trials. Circulation. 2011;123(23):2736-2747. https://doi. org/10.1161/circulationaha.110.009449

PMid:21670242

14. Pisters R, Lane DA, Nieuwlaat R, de Vos CB, Crijns HJ, Lip GY.
A novel user-friendly score (HAS-BLED) to assess 1-year risk of major bleeding in patients with atrial fibrillation. Chest. 2010;138(5):1093-1100. https://doi.org/10.1378/chest.10-0134 PMid:20299623

15. European Medicines Agency. Guidelines on Bioanalytical Method Validation; 2012. Available from: http://www.ema.europa.eu/ docs/en_GB/document_library/Scientific_guideline/2011/08/ WC500109686.pdf. [Last accessed on 2018 Mar 20].

16. Sornsuvit C, Niamhun N, Luengpiansamut N, Sangsrijan S, Niwatananum W, Kaewvichit S, et al. Pharmacokinetics and bioequivalence studies of warfarin sodium 5 milligrams tablet in healthy Thai subjects. Int J Pharm Pharm Sci. 2015;7:219-22.

17. Chua YA, Abdullah WZ, Gan SH. Development of a highperformance liquid chromatography method for warfarin detection in human plasma. Turk J Med Sci. 2012;42:930-41.

18. Sun S, Wang M, Su L, Li J, Li H, Gu D. Study on warfarin plasma concentration and its correlation with international normalized ratio. J Pharm Biomed Anal. 2006;18;42:218-22.

PMid:16860509

19. Kwon MJ, Kim HJ, Kim JW, Lee KH, Sohn KH, Cho HJ, et al. Determination of plasma warfarin concentrations in Korean patients and its potential for clinical application. Korean J Lab Med. 2009;29:515-23. https://doi.org/10.3343/ kjlm.2009.29.6.515

PMid:20046082

20. McDonald MG, Rieder MJ, Nakano M, Hsia CH, Rettie AE. Cyp4f2 is a Vitamin K1 oxidase: An explanation for altered warfarin dose in carriers of the V433m variant. Mol Pharmacol. 2009;75(6):1337-46. https://doi.org/10.1124/mol.109.054833 PMid:19297519

21. Cain D, Hutson SM, Wallin R. Assembly of the warfarinsensitive Vitamin $\mathrm{K}$ 2,3-epoxide reductase enzyme complex in the endoplasmic reticulum membrane. J Biol Chem. 1997;272:29068-75. https://doi.org/10.1074/jbc.272.46.29068 PMid:9360981

22. Kamali F, Khan TI, King BP, Frearson R, Kesteven P, Wood P, et al. Contribution of age, body size, and CYP2C9 genotype to anticoagulant response to warfarin. Clin Pharmacol Ther. 2004;75(3):204-12. https://doi.org/10.1016/j.clpt.2003.10.001 PMid:15001972

23. Xue L, Holford N, Ding X, Shen Z, Huang C, Zhang H, et al Theory-based pharmacokinetics and pharmacodynamics of S- and R-warfarin and effects on international normalized ratio: Influence of body size, composition and genotype in cardiac surgery patients. $\mathrm{Br} \mathrm{J}$ Clin Pharmacol. 2017;83(4):823-35. https://doi.org/10.1111/bcp.13157 PMid:27763679

24. Herman D, Locatelli I, Grabnar I, Peternel P, Stegnar M, Mrhar A, et al. Influence of $\mathrm{CYP} 2 \mathrm{C9}$ polymorphisms, demographic factors and concomitant drug therapy on warfarin metabolism and maintenance dose. Pharmacogenomics J. 2005;5:193-202. https://doi.org/10.1038/sj.tpj.6500308

PMid:15824753

25. Gage BF, Eby C, Milligan PE, Banet GA, Duncan JR, McLeod HL. Use of pharmacogenetics and clinical factors to predict the maintenance dose of warfarin. Thromb Haemost. 2004;91(1):87-94. https://doi.org/10.1160/th03-06-0379 PMid:14691573

26. Gong IY, Schwarz UI, Crown N, Dresser GK, Lazo-Langner A, Zou GY, et al. Clinical and genetic determinants of warfarin pharmacokinetics and pharmacodynamics during treatment initiation. PLoS One. 2011;6(11):e27808. https://doi. org/10.1371/journal.pone.0027808 PMid:22114699

27. Lombardi R, Chantarangkul V, Cattaneo M, Tripodi A. 
Measurement of warfarin in plasma by high performance liquid chromatography (HPLC) and its correlation with the international normalized ratio. Thromb Res. 2003;111(4-5):281-4. https://doi. org/10.1016/j.thromres.2003.09.006

PMid:14693176

28. Rusdiana T, Araki T, Nakamura T, Subarnas A, Yamamoto K. Responsiveness to low-dose warfarin associated with genetic variants of VKROC1, CYP2C9, CYP2C19, and CYP4F2 in an Indonesian population. Eur J Clin Pharmacol. 2013;69(3):395405. https://doi.org/10.1007/s00228-012-1356-9

PMid:22855348

29. Mansur AP, Takada JY, Avakian SD, Strunz CM. Warfarin doses for anticoagulation therapy in elderly patients with chronic atrial fibrillation. Clinics. 2012;67:543-6. https://doi.org/10.6061/ clinics/2012(06)01

PMid:22760890

30. Gallagher AM, Setakis E, Plumb JM, Clemens A, van Staa TP Risks of stroke and mortality associated with suboptimal anticoagulation in atrial fibrillation patients. Thromb Haemost. 2011;106(5):968-77. https://doi.org/10.1160/th11-05-0353 PMid:21901239

31. Kearon C, Ginsberg JS, Kovacs MJ, Anderson DR, Wells P, Julian JA, et al. Comparison of low-intensity warfarin therapy with conventional-intensity warfarin therapy for longterm prevention of recurrent venous thromboembolism N Engl J Med. 2003;349(7):631-9. https://doi.org/10.1016/j. accreview.2003.09.054

PMid:12917299 